\title{
Problems of control of land-use of research establishments and educational institutions
}

\author{
L. Novakovskyi, \\ academician NAAS, doctor of economic sciences NAAS
}

The purpose. To consider acting legal regime, contents and state of use of lands of scientific institutes and educational institutions, and also features of legislative offers on disproportionation of the specified lands and their exception. Methods. Analysis, synthesis, generalization. Results. Directions and mechanisms of protection of lands of agrarian science and educational-pilot farms of higher educational establishments from unreasonable exception are offered. Conclusions. For years of independence of Ukraine the land reserves of National academy of agrarian sciences were devided out to $37 \%$. Protection of lands of science which are national property and require special guard has become a nation-wide problem. Its solution requires adoption of the separate law on lands of research and development establishments and educational institutions, the main points of which should contain norms of heightening the status of state organs on control of these lands, exclusion of their privatization and exception or alienation depending on the functional zoning.

Key words: research and development establishments, educational institutions, land-use of scientific and educational establishments, exception of lands, permanent use, functional zones, pilot farms.

Lands of all nine categories are used by scientific institutions, enterprises and organizations of the National Academy of Agrarian Sciences of Ukraine. It is the well-known facts that the legal regime of land use of each category has certain differences. But the lands of agricultural occupy the largest areas all the territory of Ukraine. They are provided to research institutions and educational institutions and rural vocational schools for research and training purposes, and to promote best practices in agriculture [4]. Unlike citizens, agricultural enterprises, non-agricultural, religious organizations, associations of citizens, who can be provided land for commercial agricultural production and auxiliary agriculture, research institutions and educational institutions do not have the task of conducting such activities. These features should be taken into account in the formation of the relevant land use and the implementation of land relations management in relation to the specific legal regime established by the current legislation [10].

Of the 10.5 million hectares of agricultural land allocation 503.2 thousand hectares are been in state own and $4.9 \%$ are been in constant use by state agricultural research institutions and educational institutions. $92.5 \%$ of this area (465 thousand hectares) arebeen by the lands of scientific institutions, enterprises and organizations of the National Academy of Agrarian Sciences of Ukraine.

Regardless to the fact that the absolute majority of the available areas of science and education are used by research and educational facilities, without which the process of research and training of the corresponding personnel can not occur at all, also the pressure from the state and self-governing bodies to deprive or reduce the lands of science and education has increased considerably in recent years. That fact was affected the legislative activity of the Parliament and the Government, as well as in the regulation of land relations by local councils and local state administrations.

Privatization (with covenants) and the liquidation of inefficient enterprises, institutions and organizations of the National Academy of Agrarian Sciences were provided by, the coalition agreement of the parliamentary factions of the VerkhovnaRada of the 8th convocation [3].

According to the Law on the State Budget of Ukraine for 2015, executive authorities and National and Sectoral Academy of Sciences are requested to ensure the transfer of state-owned land plots for lease on a competitive basis with a view to their effective use, by the way the purposeful and functional assignment are not takeninto attention. It is also ignored that the experimental fields and most of the soil types of land 
plots of science are of particular value and may be withdrawn in exceptional cases. This norm has been extended in the Laws on the State Budget for 2016 and 2017 [9].

There are also some cases where local authorities ignore the norms of the Law with the consent of the Presidium of the Academy of Sciences on the withdrowal of land from the permanent use of scientific institutions. These withdrowal were carried out by land authorities that did not have the authority to extract land from the law.

The occupation of lands of national academies and educational institutions for other purposes is initiated by separate deputies of Ukraine. The bill "On Amendments to Certain Legislative Acts of Ukraine on Improving the Investment Climate in the Field of Agricultural Products Production" was submitted for review to the VerkhovnaRada on September 1, 2015 [6].That bill gives the rightfor the Cabinet of Ministers to transfer agricultural land to state property for use on the basis of production-sharing agreements. Such agreements, according to the current legislation, are concludedin the field of minerals, and provided that company invests in investments, establishes infrastructure and provides extraction of minerals, and the state receives from the investor a certain percentage of the output.

There are citizens of Ukraine, foreigners, stateless persons, legal entities of Ukraine or another state, associations of legal entities established in Ukraine or abroad, as well as persons who has financiallyeconomic and technical capabilities or appropriate qualifications for the production of agricultural products.

The Government may exercise the right to extract sites permanently used by state and municipal scientific institutions and educational institutions used for research purposes in cases when:

a) financing of research work is missing;

b) the size of the land is excessed the needs of scientific institutions and educational institutions for the educational process, scientific research, cultivation of elite grain material, also the need for breeding stock of livestock in feed;

c) materials of state control over the use and protection of land have conclusions about the need for other use of state-owned land;

d) the plot is used in violation of the law.

All these cases can be created artificially, especially when this is not public funding for research. That bill was supported by the Verkhovna Rada Committee on Economic Policy and submitted to the session for consideration in the first reading, but has not been considered yet regardless the recognition of the bill on corruption and the proposal for its rejection by the Scientific Expert Board and the Verkhovna Rada of Ukraine Committee on European Integration.

Taking into account that the land use of agrarian science in modern conditions requires reliable legal protection, the Academy Presidium submitted draft legislative acts to the Government and Committees of the Verkhovna Rada for consideration, twice appealed personally to the Prime Minister of Ukraine with a request to preserve and protect the lands of scientific institutions. The NAAN General Meeting appealed to the President of Ukraine, the Chairman of The Verkhovna Rada of Ukraine, the Prime Minister of Ukraine with the relevant petition for the protection of lands of agrarian science [2].

Despite the fact that the tasks of agrarian science over the years of Ukraine's independence were constantly complicated, its material and technical base did not grow, but declined. During 1991-2015 pp. the amount of land use decreased by 275.5 thousand hectares (37.2\%) (from 740.8 to 465.3 thousand hectares). 219.0 thousand hectares (73 pilot farms) oh these area were transferred to the Ministry of Agrarian Policy by the Cabinet of Ministers, split or leased to agricultural holdings and other farms. The area of 25.9 thousand hectares was withdrawn without the consent of the Presidium of the Academy. 26 farms of the Academy were leased as integral property complexes (112.0 thousand hectares) according to the order of the Cabinet of Ministers of Ukraine of February 06, 2012, № 113, but this decision was canceled by the Government and the experimental base of a number of scientific institutions was restored. As a result of the annexation of the Autonomous Republic of Crimea, the land area of the Academy decreased by 25.1 thousand hectares.

The total amount of the Academy's arable land is 364.5 thousand hectares. Nowdays from these area for the specific scientific purposes, 97.8 thousand hectares $(26.8 \%$ of arable land) are used for 
experimental fields (developmental rational methods of conducting scientifically grounded agriculture and the introduction of soil protection systems; 117.1 thousand hectares $(32.1 \%$ of arable land) are used for the production of elite seeds and seeds of higher reproductions of the selection of scientific establishments of the Academy and planting material of agricultural crops. To provide breeding stock,

61.3 thousand hectares (16.8\% of arable land area) are used as a proper forage and pedigree production. For scientifically grounded crop rotation and to comply with the parameters of spatial isolation of the placement of crops grown for seeds, 88.3 thousands hectares $(24.3 \%$ of the total arable land) is allocated for the production of commodity crop production.

A separate bill "On the Land of Research Institutions and Educational Institutions" has been prepared and submitted the Presidium of the Academy for consideration by the Verkhovna Rada of Ukraine taking into account the necessity of legal protection of the lands of science and education.

The bill has provided for amendments to the Land Code of Ukraine, supplementing Chapter 5 "Agricultural lands" [1] with a new article 24-1 in the following wording:

"Article 24-1. Land of research institutions and educational institutions.

1. Land plots for scientific research and educational purposes are provided for permanent use for research facilities and educational institutions of state and communal forms of ownership.

State and municipal research institutions and educational institutions can lease land plots owned by individuals and legal entities.

2. Land for scientific research and educational purposes are transferred to private ownership for research institutions and educational institutions.

Private research institutions and educational institutions may lease land plots of state, communal and private ownership.

3. Plots for scientific research and educational purposes are used in accordance with land management projects regarding the organization of their territory.

4. Removal of land plots of research institutions, organizations and enterprises of the National Academy of Sciences of Ukraine, national branch academies of sciences, which are in their constant use, shall be carried out in accordance with the procedure established by law with the consent of the heads of these institutions, organizations and enterprises, and only with the consent of the Presidium of the National the Academy of Sciences of Ukraine, national branch academies of sciences, and land plots that are in constant use of higher educational institutions - with the consent of the heads of these institutions, and also but only with the consent of the central executive authority on education and science.

5. Expropriation for public needs and grounds of public necessity of land plots that are owned by private research institutions and educational institutions is conducted in accordance with the procedure established by law.

6. Privatization, seizure and expropriation of lands of state, communal and private research institutions and educational establishments, the mode of use, protection and reproduction of which is caused by functional zoning, is not allowed, including: areas of scientific research fields; areas of cultivation of elite seed and gardening material of agricultural crops; zones of testing of new technology, propaganda of scientific developments; zones of conservation of valuable for research agro-land, nature conservation and historical and cultural objects.

The decision on this issue has not yet been taken. However, the Cabinet of Ministers of Ukraine [7], and some people's deputies insist on reducing the land area of the institutions and organizations of the Academy.

In October last year, the People's Deputy of Ukraine Yuri Timoshenko presented a bill "On Amendments to Certain Legislative Acts of Ukraine (regarding the proper provision of territorial communities by land resources)" [5]. This project was considered at the meeting of the Committee on Science and Education of the Verkhovna Rada of Ukraine in January 2017.

In the submission to the bill it is indicated that the National Academy of Agrarian Sciences of Ukraine and its subordinate bodies do not carry out research activity on the entire area of especially valuable land that is in their permanent use. 
A part of the land is sub-leased and transferred to the actual use by economic entities under the cover of contracts, contracts for agricultural products and, so-called, contracts for the provision of services for the cultivation of commercial scientific and technical agricultural products, resulting in the budget is not a significant amount money.

As a result of ineffective and sometimes unprofitable activities of the National Academy of Agrarian Sciences of Ukraine and its subordinate bodies, at the disposal of the Academy there were only 360 thousand hectares of land with 1 million hectares, which she had on her balance. Numerous territorial communities are constantly faced with a shortage of land resources, if necessary, the location of social facilities of approximately 2-3 hectares (insignificant compared to the area occupied by the academy), and the mechanism for the removal of land plots provided for by the Land Code of Ukraine is blocked.

Attention is drawn to the presentation of information that does not correspond to reality, which occurs not only in this representation, but also in other similar documents. When Ukraine became independent, the land area of the Academy amounted to 740 thousand hectares or 260 thousand was less than the author points out. The modern area reaches 465 thousand hectares or 105 thousand is larger than the people's deputy notes. And the reduction of land use, might not be considered an illegal activity of the Academy mainly by the decision of the Cabinet of Ministers.

By the way It would be appropriate to note that the Academy is involved in providing ATO participants with land plots at the expense of subordinated farms in many areas of the country.

The bill proposes to resolve the issue of providing territorial communities with land resources by simplifying the procedure for extracting land plots of especially valuable land occupied by experimental fields, with the permanent use of the National Academy of Agrarian Sciences of Ukraine, other academies and higher educational establishments.

The land of research fields of research institutions and educational institutions in accordance with Article 150 of the Land Code of Ukraine are particularly valuable lands, which are used exclusively for scientific research and provide the basic functions of the activities of these institutions and institutions. Therefore, their uncontrolled withdrawal, which is allowed by the bill, contradicts the provisions of Articles 8 and 12 (concerning the powers of regional rural, settlement, city councils and their executive bodies in the field of land relations), Article 20 (regarding the establishment and modification of the intended use of land plots) of the Land Code Ukraine and might lead to the loss of the integrity of scientific and production and experimental activities.

Given the foregoing, it was considered inappropriate to change the procedure for the withdrawal of such lands and to amend the existing version of paragraph "c" of part one of Article 150 of the Land Code of Ukraine. This position was supported by the Committee of the Verkhovna Rada of Ukraine on Science and Education and the State service Ukraine on geodesy, cartography and cadastre.

A number of issues of land use of science and education is envisaged to be resolved in the bill number 4355 dated March 31, 2016, which was prepared for consideration in the second reading in October last year [8]. The bill "On Amendments to Certain Legislative Acts on Extending the Authorities of Local Self-

Government Bodies to Land Resources Management and Strengthening State Control over Land Use

and Protection" stipulates that the state ownership would be acquired and implemented by the state not only through executive bodies, but also by rural , township, city councils (Article 84 of the Code).

A new norm is introduced according to which land owned and land owned by the state owned land that can not be transferred to the communal property:

a) used by state authorities, enterprises, institutions, organizations, including for the activities of the Verkhovna Rada of Ukraine, the President of Ukraine, the Cabinet of Ministers of Ukraine, other bodies of state power, the National Academy of Sciences of Ukraine, national branch academies of sciences.

Land plots are owned by the state, included in the boundary of the settlement (except for land that might not be transferred to communal property) are transferred to the ownership of a territorial community (Article 117 of the Code).

Article 122 of the Code stipulates that the land plots of the National Academy of Sciences of Ukraine, national branch academies of sciences and enterprises that are assigned to the sphere of their management, are transferred for use exclusively by the Cabinet of Ministers of Ukraine 
Land provided for permanent use from the state-owned land of the National Academies of Sciences may be withdrawn only by the Cabinet of Ministers of Ukraine (Article 149 of the Code).

\section{Conclusions}

In recent years, the number of groundless reductions in land use of science and education have grown significantly, which is the main base for conducting research in the field of development of the agroindustrial complex and training of the corresponding personnel. During the years of independence, the state fund of the National Academy of Agrarian Sciences decreased by 37\%. The protection of the land, which is most valuable in the majority, is a national heritage and requires special protection, has turned into a national problem. Its decision stipulates the adoption of a separate law on the land of research institutions and educational institutions, the main provisions of which should include the rules for increasing the status of state bodies for the management of these lands, the prohibition of their privatization and seizure or alienation, depending on functional zoning.

\section{References}

1. Land Code of Ukraine dated October 25, 2001 No. 2768-III // Bulletinof the Verkhovna Rada of Ukraine. -2002. № 3-4. - Art. 27

2. Report on the activities of the National Academy of Agrarian Sciences for 2011-2015 and 2015. K .: Agrar. science, 2016. 464 pp.

3. Coalition agreement of the parliamentary factions of the Verkhovna Rada of Ukraine of the 8th convocation. [Electronic resource] - access mode: http://www.afo.com.ua/doc/Coalition_Agreement_ 2014.pdf

4. Novakovskaya I.O. Basics of land use economics: [monograph] / I.O. Novakovskaya. - K .: Prosvita, 2013. - $242 \mathrm{pp}$.

5. On amendments to certain legislative acts of Ukraine on the proper provision of territorial communities by land resources: Draft Law dated July 12, 2016, Reg. № 4957. [Electronic resource] access mode: http: // www. rada.gov.ua

6. On Amending Certain Legislative Acts of Ukraine on Improving the Investment Climate in the Field of Agricultural Products Production: Draft Law dated September 1, 2015, Reg. No. 3002. [Electronic resource] - access mode: http: // www. rada.gov.ua

7. On amendments to certain legislative acts of Ukraine regarding the termination of rights to use land plots of enterprises, institutions and organizations under the authority of the National Academy of Sciences or the National Branch of the Academy of Sciences: Bill of May 04, 2016, Reg. No. 4554. [Electronic resource] - access mode: http: // www. rada.gov.ua

8. On Amendments to Certain Legislative Acts of Ukraine on the Extension of Authorities of Local SelfGovernment Bodies to Land Resources Management and Strengthening State Control over the Use and Protection of Land: Draft Law dated March 31, 2016, Reg. No. 4355. [Electronic resource] - access mode: http: // www. rada.gov.ua

9. About the State Budget of Ukraine for 2017: Law of Ukraine dated December 21, 2016, No. 1801VIII // Official bulletin of Ukraine 2016. No 101. Art. 3291

10. On scientific and scientific and technical activities: Law of Ukraine dated November 26, 2015 No. 848-VIII / Information from the Verkhovna Rada of Ukraine. 2016.- No. 3. - Art. 25 